\title{
Native Ornamental Potted Plants for Sustainable Improvement of Indoor Air Quality
}

\author{
Hamdan Mohd Noor ${ }^{1, ~ *, ~ H a n i m ~ A h m a d ~}{ }^{2}$ \\ ${ }^{1}$ Horticulture Research Centre, Malaysian Agricultural Research and Development Institute, Serdang, Malaysia \\ ${ }^{2}$ Industrial Crop Research Centre, Malaysian Agricultural Research and Development Institute, Serdang, Malaysia
}

Email address:

hamdanor@mardi.gov.my (H. M. Noor), hanim@mardi.gov.my (H. Ahmad)

${ }^{*}$ Corresponding author

To cite this article:

Hamdan Mohd Noor, Hanim Ahmad. Native Ornamental Potted Plants for Sustainable Improvement of Indoor Air Quality. International Journal of Applied Agricultural Sciences. Vol. 6, No. 3, 2020, pp. 44-51. doi: 10.11648/j.ijaas.20200603.13

Received: March 30, 2020; Accepted: May 11, 2020; Published: June 4, 2020

\begin{abstract}
Ornamental potted plant are often proposed as a passive approach for improving indoor air quality (IAQ). Volatile organic compounds (VOCs) enter indoor environments through internal and external sources. Indoor air concentrations of VOCs vary greatly but are generally higher than outdoors. Plants have been promoted as indoor air purifiers for decades, but reports of their effectiveness differ. The aim of this study was to determine the selective of several potted indoor and outdoor species plants which can sustain and improve indoor air quality by using the native species plants. The experimental design was a complete randomised design experiment with four replications and it was conducted at the Horticulture Research Centre laboratory. Different native ornamental potted plants species such as Eugenia sp.; Scindapsus pictus; Schismatoglottis sp.; Tradescantia pallida; Piper porphyrophyllum; Alocasia reginula; Ledebouria socialis; Peperomia sp. and Ledebouria petiolata respectively had a different significant effects on absorption of the VOCs gases. The maximum and significant absorption of potted indoor plants species tested sequently was from Ledebouria socialis; Eugenia sp.; Piper porphyrophyllum; Peperomia sp.; Scindapsus pictus; Tradescantia pallida; Ledebouria petiolata; Alocasia reginula and Schismatoglottis sp. The leaf area, having moderate function of VOCs gas absorption did not drastically reduce the VOCs gas volume. Overall, the data from the laboratory studies illustrate the potential for indoor plants leaves to be used as air purifier and indoor air VOC samplers.
\end{abstract}

Keywords: Indoor Plant, Native Species, Volatile Organic Compounds (VOCs), Air Purifier, Air Quality, Pollutants

\section{Introduction}

The potential exposure to volatile organic compounds (VOCs) in indoor air have increased as new home construction techniques and improvement have significantly reduced the introduction of outdoor air. Such techniques and improvement include heating, ventilation and air conditioning efficiency [1]. Concentrations of VOCs in indoor air are generally 5-10 times higher than outdoors, with even higher indoor air concentrations in extreme cold weather [2]. Air pollutants common to different indoor environments include carbon monoxide and dioxide $\left(\mathrm{CO}\right.$ and $\left.\mathrm{CO}_{2}\right)$, volatile organic compounds (VOCs; e.g., formaldehyde and benzene), nitrogen oxides ( $\mathrm{NO}$ and $\mathrm{NO}_{2}$ ), and polycyclic aromatic hydrocarbons (PAHs) [3, 4]. Since people in industrialized countries spend more than $80 \%$ of their lives indoors $[5,6]$, the build-up of air pollutant concentrations to dangerous levels, especially in modern energy-saving but air-tight constructions, represents one of the priority concerns for human health today $[7,8]$. In fact, continuous exposure to air pollutants, the concentration of which is higher indoors than outdoors [9], may cause respiratory and cardiovascular diseases eventually contributing to the so-called 'sick building syndrome' (SBS) and 'building-related illnesses' (BRI) [10, 11]. One of the major concerns involves formaldehyde, a widespread hazardous air pollutant that is released over the long-term from aging furniture and pressed-wood products, and that is likely to have carcinogenic effects on humans [12].

In addition, potentially toxic gases and particular matter can be released by a variety of indoor sources and activities of occupants including furnishings, paints, paint strippers, varnishes, waxes, carpets, solvents, cleaning supplies, office equipment such as copiers and printers, gas cook tops, 
cigarettes [13] and external sources (e.g. vapor intrusion from contaminated soil and/or groundwater and ambient air from automobiles and industrial facilities. Ornamental plants have been used to reduce indoor air concentration of VOCs $[14,15]$ Thereby, the plants act as sinks and consequently reduce the VOC concentration in the air. However, stated removals differ widely and the variety of experimental approaches used to determine removals complicate comparisons among studies.

A research by Baur [16], reported that VOCs removal mechanisms include stomatal uptake and depended on the plant and chemical of interest, microbial transformation within plant growth media [17], and sorption to leaves and plant growth media [17-19].

Far fewer studies have examined the effectiveness of plants as samplers for more volatile compounds, especially in indoor environments [20]. To investigate the potential of using plant leaves as samplers for indoor air VOCs concentrations, a static headspace approach was used to determine leaf-air concentration factors (LACFs) for VOCs as a function of VOCs concentration and plant type $[15,20]$. The relationship between leaf and air concentrations was further examined in an actual residence after the screening of the plant capability in gas absorption. Finally, the measured indoor air concentrations were compared to concentrations predicted from laboratory derived LACFs and measured leaf concentrations.

\section{Materials and Methods}

\subsection{Experimental Site and Growth Conditions}

The experiments [21] were conducted in the Horticulture laboratory which are located at the Horticulture Research Centre, MARDI, Serdang, Selangor ( $2^{\circ} 59^{\prime} 51.4374 "$ N $101^{\circ}$ 41' 26.227" E / 2.997622 $\left.{ }^{\circ} \mathrm{N} 101.690619^{\circ} \mathrm{E}\right)$.

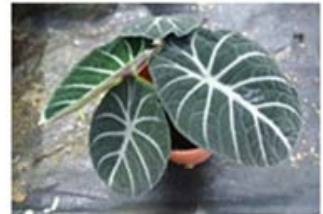

Alocasia reginula

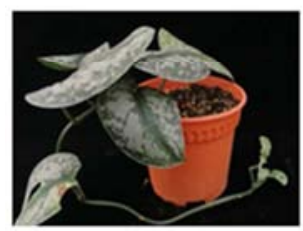

Scindapsus pictus

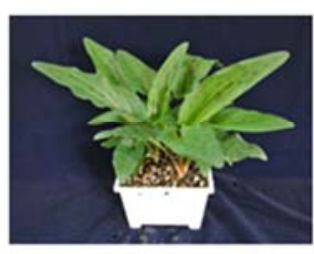

Ledebouria socialis

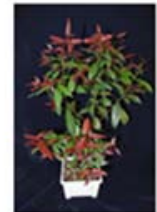

Eugenia sp.

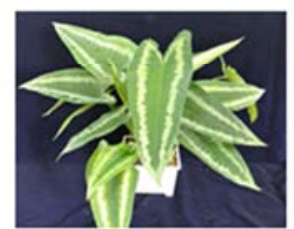

Schismatoglottis sp.

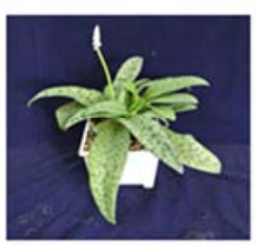

Ledebouria petiolata

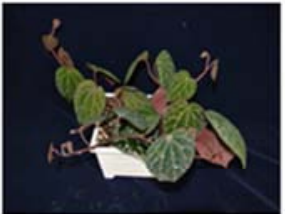

Piper porphyrophyllum

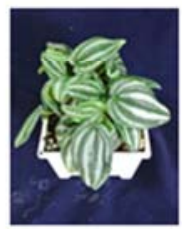

Tradescantia pallida

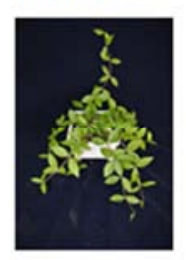

Peperomia sp
Figure 1. Native ornamental potted plants species tested for the absorbing of the VOCs gas.

\subsubsection{Plants}

Induction of VOCs removal in untested native ornamental potted plants species [22, 23]. The main aim of this more recent test-chamber study was to compare VOCs removal capacities in nine native common houseplants species: Piper porphyrophyllum; Tradescantia pallida; Schismatoglottis sp.; Alocasia reginula; Scindapsus pictus; Eugenia sp., Ledebouria socialis; Ledebouria petiolata and Peperomia sp. A second aim was to examine whether removal rates with either species could correlate with any plant or potting-mix attribute. The plants were selected because they are commonly available, always used as the indoor houseplant and are hardy. Plants were purchased locally from several different vendors and re-potted in plastic planter's pot using a $50 \%$ peat moss and $50 \%$ vermiculate mix.

\subsubsection{Treatment Systems}

Plants in $200 \mathrm{~mm}$ pots were used. Isobutylene gas [22, 24] was used as the test VOCs. Four replicate glass test chambers were used (33 cm width x $35 \mathrm{~cm}$ height x $64 \mathrm{~cm}$ length). Pots were first watered to saturation, drained for 20 minutes and placed in chambers, and an initial dose up to 4 or $5 \mathrm{ppm}$ of the Isobutylene was injected into the test glass chambers. Leak tests were carried out before experiments to ensure that Isobutylene removal [22] was solely related to the potted plant microcosm. Each plant will be placed for 7 days in a glass test chambers with the gas detector (model Aeroqual S500, Figures 2 and 3). This experiment will be carried out using a method developed by Kwang Jin Kim [25, 26].

1. Four replicates (chambers) of single species will be tested (replicated by times). Before commence the experiment, control chambers without plants will be tested to determine gas losses not resulting from the plants (eg. leakage, absorption, chemical reactions).

2. The chambers were placed indoor (at the Horticulture laboratory), controlled temperature was in between 22 $24^{\circ} \mathrm{C}$.

After day seventh, the plant will be measured for the leaf areas and the total numbers of the leaf for every indoor plants species.

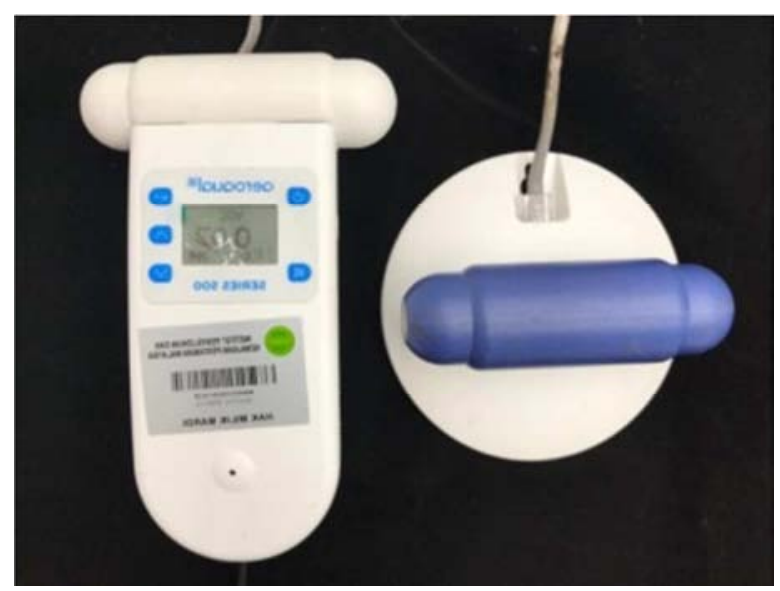

Figure 2. Gas detector (model Aeroqual S500). 


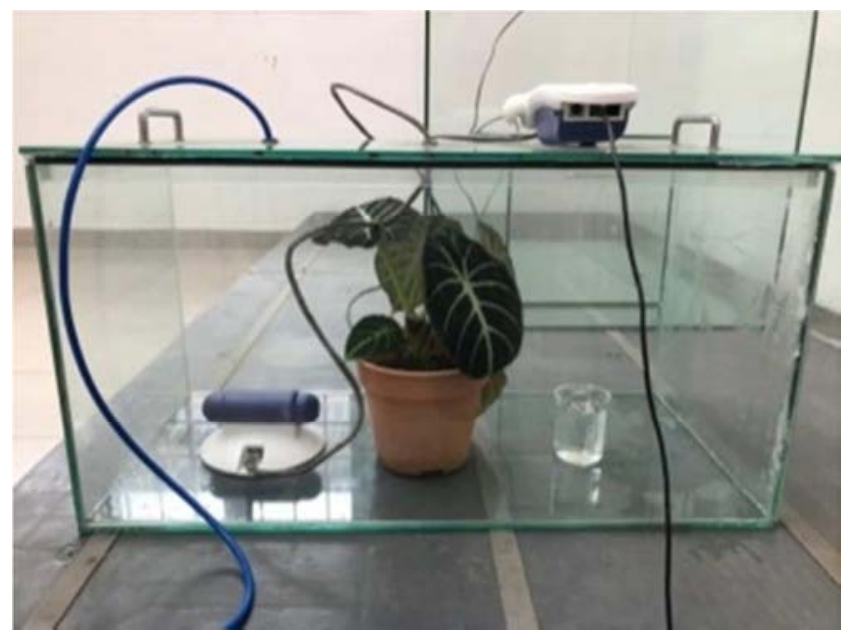

Figure 3. Glass test chamber with detector for screening the plants.

\subsection{Chemicals}

The VOCs commonly identified in indoor air monitoring surveys [22, 24] were selected for the laboratory study: isobutylene gas.

\subsection{Experimental Design and Statistical Analysis}

The experimental design was a complete randomised design (CRD) with four replications. Analysis of variance (ANOVA) was performed using the procedures of the Statistical Analysis System [27]. The Least Significant Difference (LSD) was used for test of significance.

\section{Results and Discussion}

\subsection{Screening on the Native Ornamental Potted Plants Species Against the Absorption of Volatile Organic Compound Gas Within 7 Days Duration}

Isobutylene removal rates with the nine indoor plants species are shown in Figure 4. Overall the 9 ornamental indoor plant species were analysis and screened for 160 hours. After 8 hours of screening, all native species gave a response and start absorbing the VOCs gas from the inside of glass test chamber. Result shows that Ledebouria socialis gave the best result in absorbing the isobutylene gas.

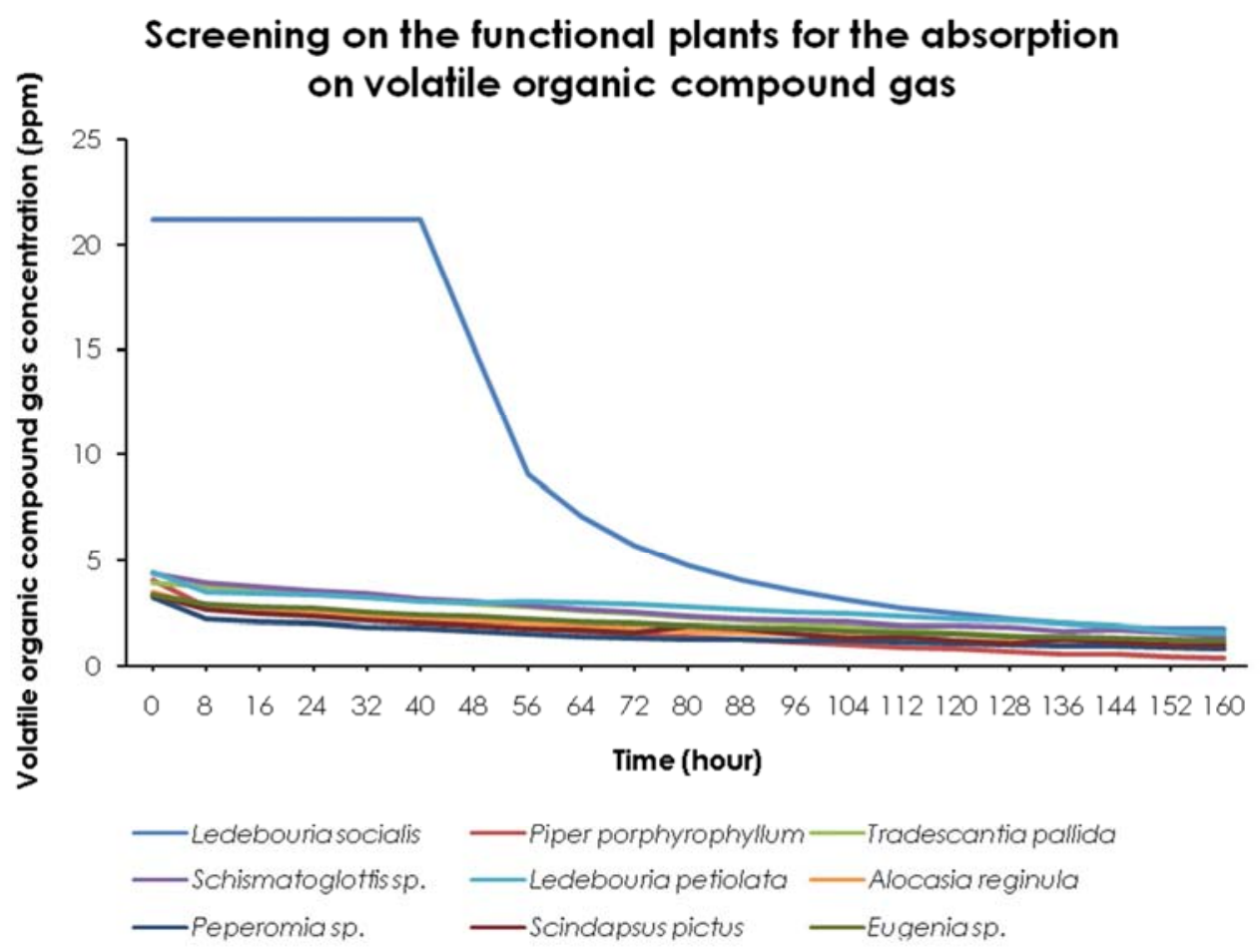

Figure 4. Screening on the native ornamental potted plants species against the absorption of volatile organic compound gas within 7 days duration using the glass chamber.

\subsection{Total Leaf Area of the Native Ornamental Potted Plants Species}

Lowest leaf area of the native plant species tested were Eugenia $s p .\left(182.50 \mathrm{~cm}^{2}\right.$ ) respectively (Figure 5). The maximum reading of $1623.27 \mathrm{~cm}^{2}$ were from Schismatoglottis species. 


\section{Leaf area $\left(\mathrm{cm}^{2}\right)$}

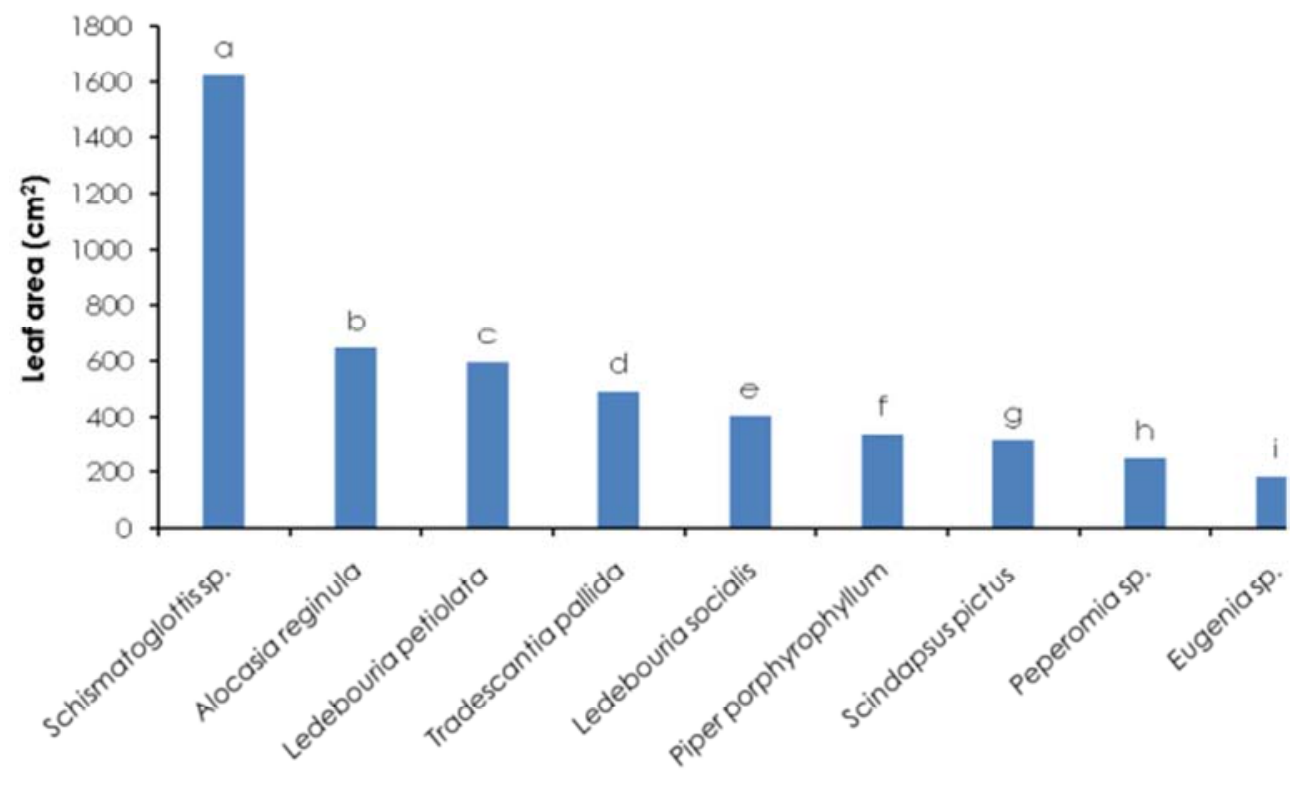

Plant species

Figure 5. Total leaf area $\left(\mathrm{cm}^{2}\right)$ of the native ornamental potted plant species Means followed by the same letter in figure were not different at $p \leq 0.05$ by the least significant difference (LSD) test.

\subsection{Total of VOC Gas Absorbed by the Native Ornamental Potted Plant Species at the Total $\mathrm{cm}^{2}$ of Leaf Area Within 7 Days Duration Using Glass Chamber}

The total of volatile organic compound gas absorbed by the total leaf area $\left(\mathrm{cm}^{2}\right)$ of the indoor plant was lowest for the Eugenia sp., Scindapsus pictus and Peperomia species respectively $(2.17,2.35$ and $2.42 \mathrm{ppm})$. The maximum and significant absorbing was recorded from Ledebouria socialis plants species $(19.47 \mathrm{ppm})$ followed by Piper porphyrophyllum plants (3.69 ppm). However, there were no significant different between Piper porphyrophyllum with Tradescantia pallida; Schismatoglottis sp.; Ledebouria petiolata and Alocasia reginula respectively (Figure 6).

\section{Volatile organic compound gas concentration (ppm)}

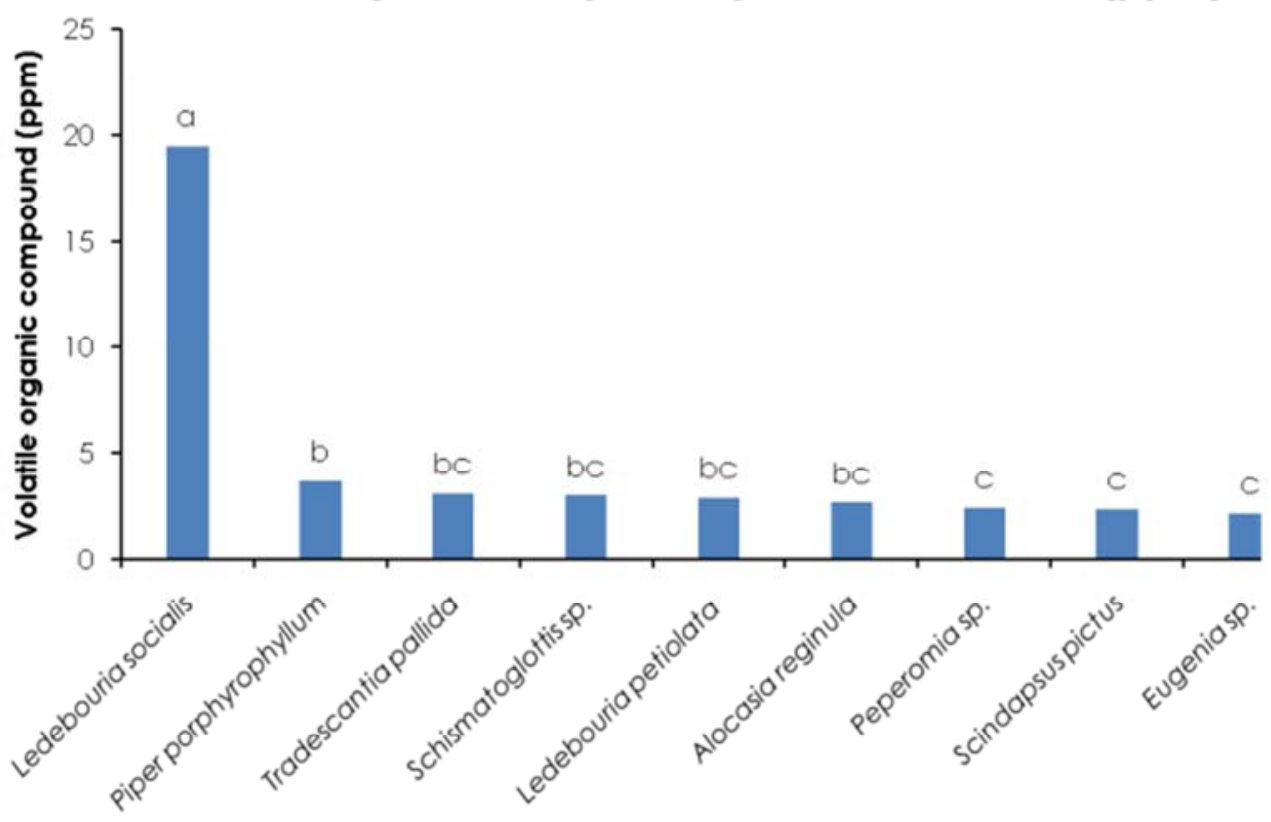

Plant species

Figure 6. Total of volatile organic compound gas absorbed by the native ornamental potted plant species at total $\mathrm{cm}^{2}$ of leaf area within 7 days duration using the glass chamber. Means followed by the same letter in figure were not different at $p \leq 0.05$ by the least significant difference (LSD) test. 


\subsection{Total of VOC Gas Absorbed on the Total Leaf Area by the Native Ornamental Potted Plant Species Within 7 Days Duration Using Glass Chamber}

Overall, the result in the Figure 7, shows that even though
Schismatoglottis sp. $\left(1623.27 \mathrm{~cm}^{2}\right)$ had the biggest total leaf area among the others plant species tested, but it was not effective in absorbing if compared to the Ledebouria socialis $\left(402.17 \mathrm{~cm}^{2}\right)$ plants species.

\section{Leaf area $\left(\mathrm{cm}^{2}\right)$ vs volatile organic compound (ppm)}

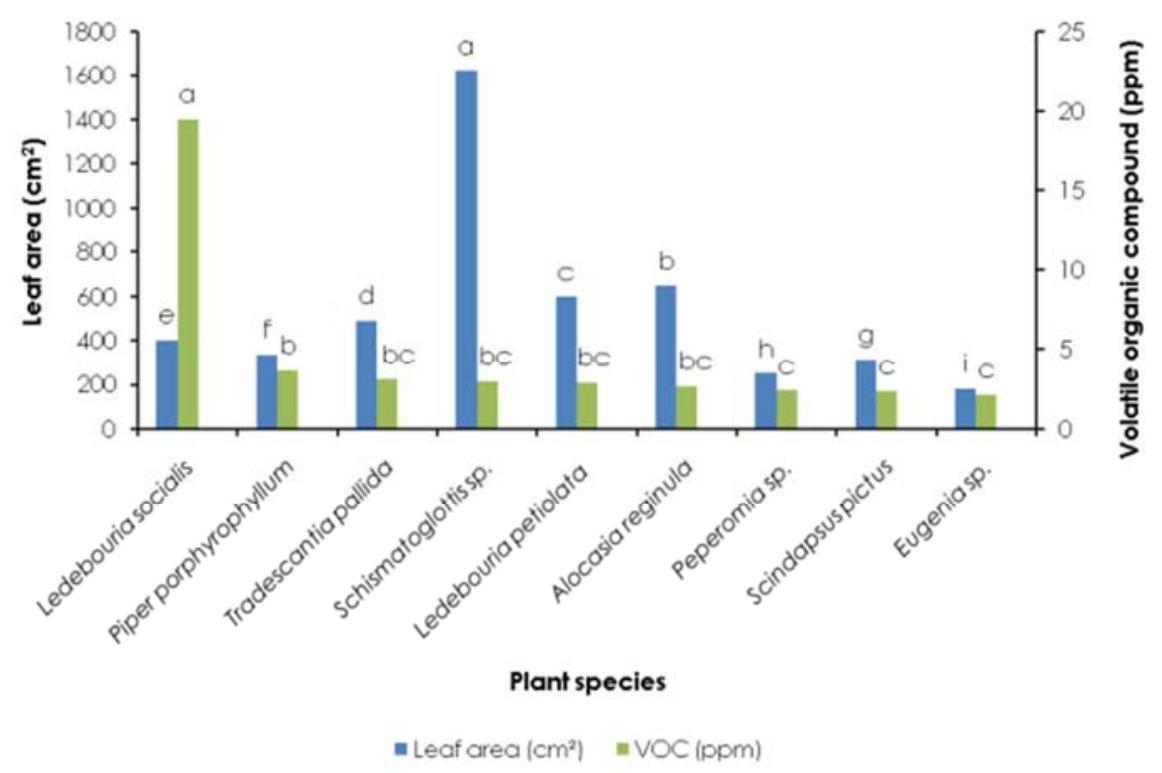

Figure 7. Total of volatile organic compound gas absorbed compared with the total leaf area (cm ${ }^{2}$ ) of native ornamental potted plants species within 7 days duration using the glass chamber. Means followed by the same letter in figure were not different at $p \leq 0.05$ by the least significant difference (LSD) test.

3.5. Total of VOC Gas Absorbed Compared on Every $1 \mathrm{~cm}^{2}$ of the Total Leaf Area of the Native Ornamental Potted Plants Species Within 7 Days Duration

Results obtained showed that Ledebouria socialis ( $0.0484 \mathrm{ppm})$ gave the highly significant and the greatest in total of volatile organic compound gas absorbed compared with the total leaf area of the native plant species within 7 days (Figure 8). Meanwhile, the Eugenia sp. (0.0119 ppm) did not have significant different when compared between Piper porphyrophyllum $(0.0110 \mathrm{ppm})$ and Peperomia sp. (0.0097 ppm).

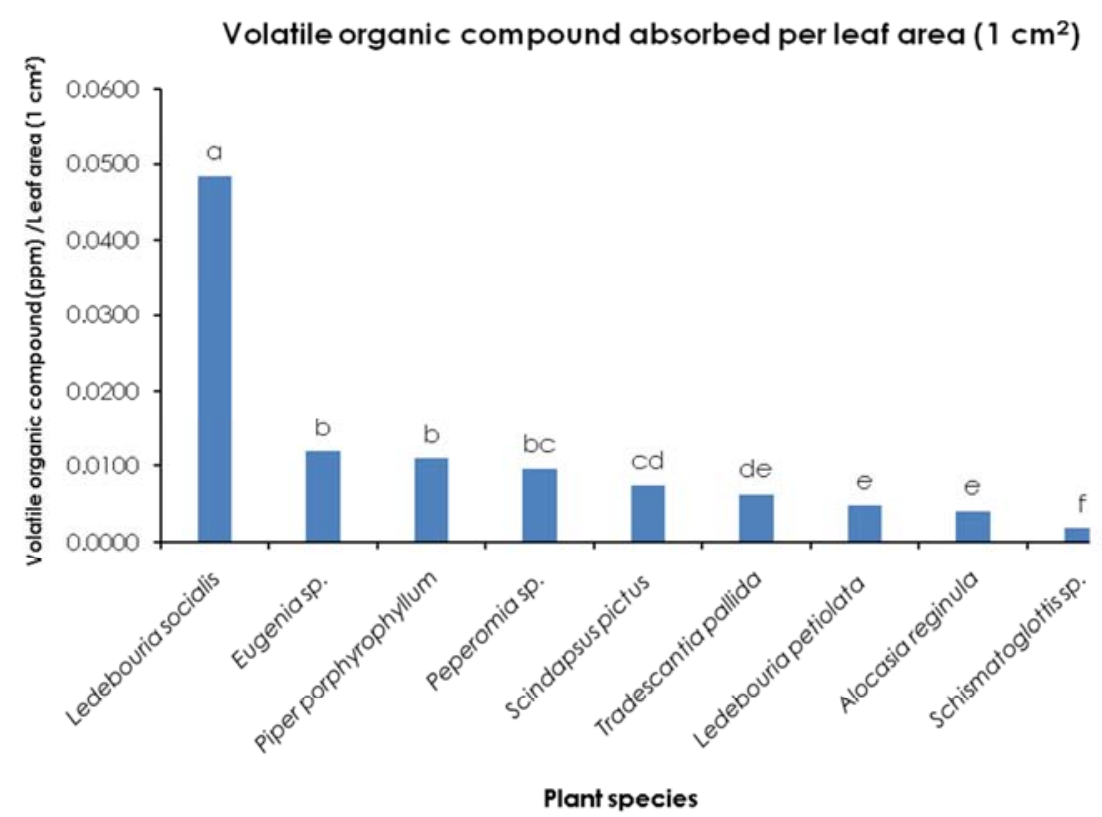

Figure 8. Total of volatile organic compound gas absorbed by the native indoors plant species at every $1 \mathrm{~cm}^{2}$ of leaf area within 7 days duration using the glass chamber. Means followed by the same letter in figure were not different at $p \leq 0.05$ by the least significant difference (LSD) test. 


\subsection{Screening on the Native Plants of the Effectiveness in Absorbing the Volatile Organic Compound Gas Within 7 Days Duration Using Glass Chamber}

Result in Figure 9 showed more detail which presents the accuracy of the effectiveness on the native indoor plant species based on the calculation of the leaf area $\left(\mathrm{cm}^{2}\right)$ vs volatile organic compound absorption in $1 \mathrm{~cm}^{2}$ of the plant species leaf area. Ledebouria socialis. (0.0484 ppm) was most effective in absorbing the volatile organic compound gas if compared between others native ornamental potted plant species tested. While the Schismatoglottis sp. (0.0018 ppm) was determined as the least effective in absorbing the volatile organic compound gases.

\section{Leaf area $\left(\mathrm{cm}^{2}\right)$ vs volatile organic compound per leaf area $\left(1 \mathrm{~cm}^{2}\right)$}

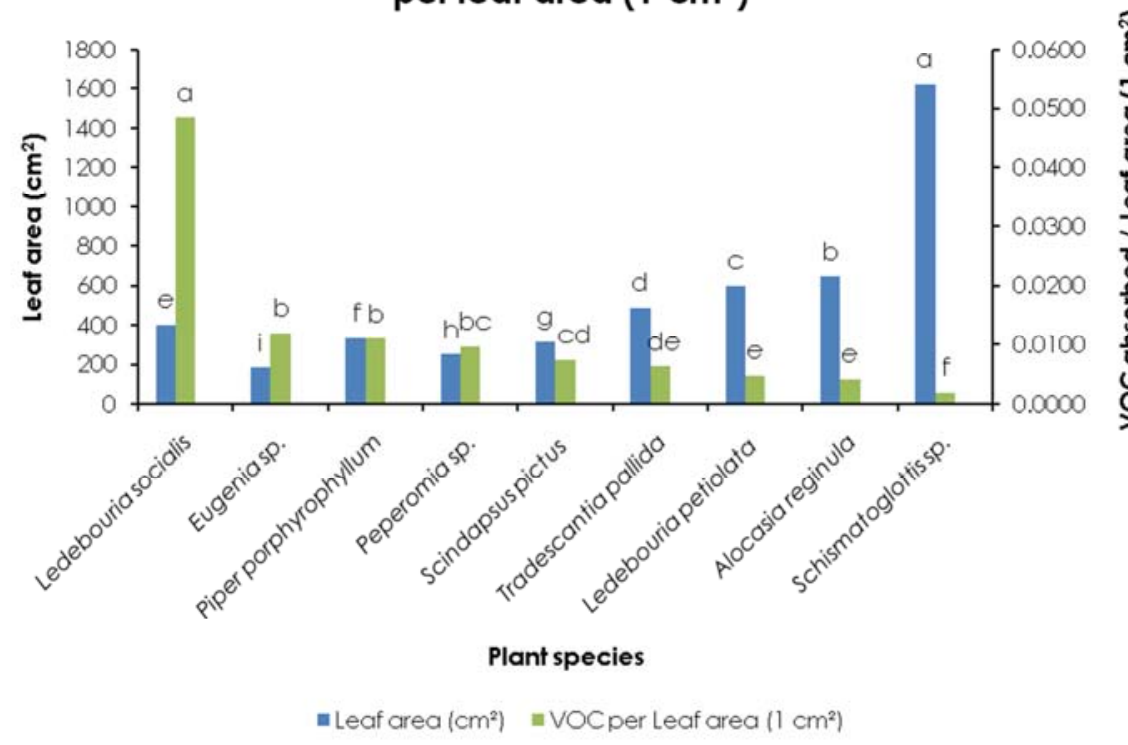

Figure 9. Total of volatile organic compound gas absorbed compared with the total VOCs (ppm) gas absorption of $1 \mathrm{~cm}^{2}$ leaf area of native ornamental potted plants species within 7 days duration using the glass chamber. Means followed by the same letter in figure were not different at $p \leq 0.05$ by the least significant difference (LSD) test.

\subsection{Determination of the Potential on the Native Indoor Plant Species for the Air Quality Improvement}

The results of all these studies, summarised below, demonstrate the ability of indoor potted plants to eliminate indoor VOCs [B]. The absorption involving parallel relationship between leaf and air VOCs [22, 24] concentrations within the residence illustrates the potential for using leaves as real time air samplers. Due to the screening result on the selected native ornamental potted plants species, according to the effectiveness of the absorbing of VOCs gas per total leaf area $\left(\mathrm{cm}^{2}\right)$ sequently showed that it was greatest in Ledebouria socialis, followed in decreasing order by Piper porphyrophyllum; Tradescantia pallida; Schismatoglottis sp.; Ledebouria petiolata; Alocasia reginula; Peperomia sp.; Scindapsus pictus and Eugenia sp. with values of 19.47; 3.69; $3.09 ; 2.98 ; 2.88 ; 2.67 ; 2.42 ; 2.35$ and $2.17 \mathrm{ppm} / \mathrm{cm}^{2}$ respectively (Figure 6 and Table 1).

However, in terms of the total leaf area of the native ornamental potted plant species showed in Figure 5, that it was greater in the Schismatoglottis sp.; Alocasia reginula; Ledebouria petiolata; Tradescantia pallida; Ledebouria socialis; Piper porphyrophyllum; Scindapsus pictus; Peperomia sp.; and Eugenia sp.; with values of 1623.27;
$645.71 ; 596.93 ; 489.81 ; 402.17 ; 335.63 ; 315.01 ; 250.62$ and $182.50 \mathrm{~cm}^{2}$ respectively. In addition, a more actual and powerful performance of the native ornamental potted plants species tested on the effectiveness for the absorbtion of VOCs gas per $1 \mathrm{~cm}^{2}$ (based on the calculation of the leaf area $\left(\mathrm{cm}^{2}\right) \mathrm{vs}$ volatile organic compound absorption in $1 \mathrm{~cm}^{2}$ of the plant species leaf area) were sequently determined as the Ledebouria socialis; Eugenia sp.; Piper porphyrophyllum; Peperomia sp.; Scindapsus pictus; Tradescantia pallida; Ledebouria petiolata; Alocasia reginula and Schismatoglottis sp. with value of 0.0484 $0.0119 ; 0.0110 ; 0.0097 ; 0.0075 ; 0.0063 ; 0.0048 ; 0.0041$ and $0.0018 \mathrm{ppm} / 1 \mathrm{~cm}^{2}$ respectively (Figure 8 and Table 2 ).

Table 1. Total of volatile organic compound gas absorbed (ppm) by the native ornamental potted plant species per total of leaf area $\left(\mathrm{cm}^{2}\right)$.

\begin{tabular}{llll}
\hline No & Plant Species & VOC $(\mathbf{p p m})$ & Leaf Area $\mathbf{( \mathbf { c m } ^ { \mathbf { 2 } } )}$ \\
\hline 1. & Ledebouria socialis & 19.47 & 402.17 \\
2. & Piper porphyrophyllum & 3.69 & 335.63 \\
3. & Tradescantia pallida & 3.09 & 489.81 \\
4. & Schismatoglottis sp. & 2.98 & 1623.27 \\
5. & Ledebouria petiolata & 2.88 & 596.93 \\
6. & Alocasia reginula & 2.67 & 645.71 \\
7. & Peperomia sp. & 2.42 & 250.62 \\
8. & Scindapsus pictus & 2.35 & 315.01 \\
9. & Eugenia sp. & 2.17 & 182.50 \\
\hline
\end{tabular}


Table 2. Total of volatile organic compound gas absorbed (ppm) by the native ornamental potted plants species per $1 \mathrm{~cm}^{2}$ of leaf area.

\begin{tabular}{|c|c|c|c|}
\hline No & Plant Species & $\begin{array}{l}\text { VOC }(p p m) \text { per } \\
\text { Leaf Area }\left(1 \mathrm{~cm}^{2}\right)\end{array}$ & $\begin{array}{l}\text { Leaf Area } \\
\left(\mathrm{cm}^{2}\right)\end{array}$ \\
\hline 1. & Ledebouria socialis & 0.0484 & 402.17 \\
\hline 2. & Eugenia sp. & 0.0119 & 182.50 \\
\hline 3. & Piper porphyrophyllum & 0.0110 & 335.63 \\
\hline 4. & Peperomia sp. & 0.0097 & 250.62 \\
\hline 5. & Scindapsus pictus & 0.0075 & 315.01 \\
\hline 6. & Tradescantia pallida & 0.0063 & 489.81 \\
\hline 7. & Ledebouria petiolata & 0.0048 & 596.93 \\
\hline 8. & Alocasia reginula & 0.0041 & 645.71 \\
\hline 9. & Schismatoglottis sp. & 0.0018 & 1623.27 \\
\hline
\end{tabular}

\section{Conclusions}

Compatibility of synthetic product is an issue in its' illustration of therapeutic benefit with the added concern of toxicity and side effects. Hence, scientific justification of the natural product in therapeutic activity would serve as a basis for the avenues of complementary and alternative environmental sources to sustainable improvement of indoor air quality as natural product $[24,28]$ minimizes the issues concerning compatibility of medication within the human body [29]. Therefore, this study aimed at identifying new and novel potential bio products based on the presence of notable nature and comparative screening evaluation on several plants species [5], allows the discover of therapeutically active natural biology sources having the potential of providing safe alternative to the adverse effects of natural products in environmental air quality [24]. This comparison of various bioactivities between different plant species in Malaysia would allow us in making a comparative justification on potential areas of further studies in order to validate the scientific evidence concretely.

The native ornamental potted plants are important for aesthetics, being the most major component of landscape designs, have historical and cultural value because of their longevity, are a potential source of useful economic products and genes for useful biomedical [29] and industrial products, as well as enhance education and recreation. Although being thought of mainly for aesthetics these plants also provide environmental and ecological services, both for the benefit of humans and other organisms. Plants also can help in a great diversity of biogenic volatile organic compounds (BVOCs), but most research on this very interesting and important topic have centred on indoor native ornamental potted plant species. The study has led us to the scientific understanding of the greater air purifier potential of the Ledebouria socialis high degree of absorbing volatile organic compounds gas as well as statistically significant inhibition of writhing shown by the plants have opened the avenue of scientific research on the discovery of noble compound that contributes to the therapeutic effect mentioned in the study.

However, the results obtained that the native indoor plants species shows the potential where the Eugenia sp.; Piper porphyrophyllum and Peperomia sp. were absorbed the VOCs gas. In addition, presence of native, exotic indoor and outdoor plants species would allow the study on the plants on its air purifier activities $[21,22,28]$ and so on. The results obtained from the bioactivity evaluation would also lead us to the evaluation screening of various indoor and outdoor plants species in the future studies to obtain pure therapeutically in absorbing VOCs significant plant sources that impart significant bioactivities, which contribute to the betterment of global healthcare.

\section{Acknowledgements}

The authors wish to express my gratitude to Malaysian Government for providing the grant for this study. Special thanks to Mr Helmey Othman, Mr Mohd Khairil Abas and Mr Abdul Aziz Mat Rasul for their technical assistance.

\section{References}

[1] Cohen, Y., 1996. Volatile organic compounds in the environment: a multimedia perspective. In: Wang, W., Schnoor, J., 1996. Doi, J. (Eds.), Volatile organic compounds in the environment. ASTM STP 1261. American Society for Testing and Materials, West Conshohocken, PA. pp. 7-32.

[2] Dales, R., Liu, L., Wheeler, A. J. and Gilbert, N. L., 2008. Quality of indoor residential air and health. Can. Med. Assoc. $179,147-152$.

[3] Desalme, D., Binet, P. and Chiapusio, G., 2013. Challenges in tracing the fate and effects of atmospheric polycyclic aromatic hydrocarbon deposition in vascular plants. Environ Sci Technol 47: 3967-3981.

[4] Geiss, O. \& Giannopoulos., Georgios \& Tirendi, S., \& Barrero, M., Josefa\& Laren, B., and Kotzias, D., 2011. The AIRMEX study - VOC measurements in public buildings and schools/kindergartens in eleven European cities: statistical analysis of the data. Atmos. Environ. 45, 3676-3684.

[5] Deng, L. and Deng, Q., 2018. The basic roles of indoor plants in human health and comfort. Environ Sci Pollut Res 25, 36087-36101. https://doi.org/10.1007/s11356-018-3554-1.

[6] Gunnarsen, L., Sigsgaard, T., Andersen, N. T., Linneberg, A., Knudsen, H. N., Afshari, A., Pedersen, C. M., Larsen, J. C. and Nielsen, E., 2006. Status og perspektiver på indeklimaområdet. Miljøministeriet, Copenhagen (in Danish).

[7] World Health Organization., 2010. WHO guidelines for indoor air quality: selected pollutants. World Health Organization, Regional Office for Europe, Copenhagen.

[8] Bruce, N. G., Perez-Padilla R. and Albalak R., 2000. Indoor Air Pollution in Developing Countries: A Major Environmental and Public Health Challenge. Bulletin of the World Health Organization. 2000; 78 (9): 1078-92.

[9] Zhang, M., Zhang, S., Feng, G., Su, H., Zhu, F., Ren, M. and Cai, Z., 2017. Indoor airborne particle sources and outdoor haze days effect in urban office areas in Guangzhou. Environ. Res. 154: 60-65.

[10] Mandin, C., Trantallidi, M., Cattaneo, A., Canha, N., Mihucz, V. G., Szigeti, T., Mabilia, R., Perreca, E., Spinazze, A., Fossati, S., De Kluizenaar, Y., Cornelissen, E., Sakellaris, I., Saraga, D., Hanninen, O., De Oliveira Fernandes, E., Ventura, G., Wolkoff, P., Carrer, P. and Bartzis, J., 2017. Assessment of indoor air quality in office buildings across Europe - The OFFICAIR study. Sci. Total Environ. 579: 169-178. 
[11] Mullen, N. A., Li, J., Russell, M. L., Spears, M., Less, B. D. and Singer, B. C., 2016. Results of the California Healthy Homes Indoor Air Quality Study of 2011-2013: Impact of natural gas appliances on air pollutant concentrations. Indoor Air 26: 231-245.

[12] Hu, D. E., Corsi, R. L., Morandi M. T. and Siegel, J. A., 2010. Formaldehyde in residences: long-term indoor concentrations and influencing factors. Indoor Air 20, 196-203.

[13] Maisey, S. J. \& Saunders., Sandra, \& West, N. and Franklin, P., 2013. An extended baseline examination of indoor VOCs in a city of low ambient pollution: Perth, Western Australia. Atmospheric. Environment. 81, 546-553.

[14] Yang, D. S., Son, K.-C., and Kays, S. J., 2009. Volatile organic compounds emanating from indoor ornamental plants. HortScience. 44 (2), 396-400.

[15] Resha, V. S., Kumar, P. and Chaitra, G. S., 2017. Significant role of ornamental plants as air purifiers - A Review. International Journal Current Microbiology Applied Sciences. 6 (8): 2591-2606.

[16] Baur, P., Marzouk, H., Schonherr, J. and Grayson, B. T., 1997. Partition coefficients of active ingredients between plant cuticle and adjuvants as related to rates of foliar uptake. Agric. Food Chem. 45 (9), 3659-3665.

[17] Orwell, R. L., Wood, R. L., Tarran, J., Torpy, F. and Burchett, M. D., 2004. Removal of benzene by the indoor plant/substrate microcosm and implications for air quality. Water Air Soil Pollut. 157. 193-207.

[18] Keymeulen, R., Bruyn, G. D. and Langenhove, H. V., 1997. Headspace gas chromatographic determination of the plant cuticle-air partition coefficients for monocyclic aromatic hydrocarbons as environmental compartment. Chromatography A 774, 213-221.

[19] Dela Cruz, M., Christensen, J. H. and Thomsen, J. D., 2014. Can ornamental potted plants remove volatile organic compounds from indoor air? - A review. Environ Sci Pollut Res 21, 13909-13928. https://doi.org/10.1007/s11356 -014 $-3240-\mathrm{x}$.

[20] Hong, S. H., Hong, J., Yu, J. and Lim, Y. W., 2017. Study on removal difference in indoor particulate matter and volatile organic compounds through application of the plants. Environ. Health Toxicol. 32: e2017006.

[21] Sumanasekara, S. A. S. L. and Jayasinghe, C., 2018. Alternative techniques to improve indoor environmental quality. Journal of Green Building, Volume 13, Number 4.

[22] Gong, Y., Zhou, T., Wang, P., Lin, Y., Zheng, R., Zhao, Y., and $\mathrm{Xu}, \mathrm{B} ., 2$ 2019. Fundamentals of Ornamental Plants in Removing Benzene in Indoor Air, Atmosphere, 10, 221; doi: 10.3390/atmos10040221.

[23] Dhanraj, D., 2019. Role of ornamental horticulture in outdoor and indoor pollution abatement - A review. Journal of Ornamental Horticulture, Volume: 22, Issue: 1and 2, pp 1-9. ISSN: 0972-0499. Online ISSN: 2249-880x. doi: 10.5958/2249 880x.2019.00001.x.

[24] Irwan, S., Mardiyati., Jooned, H. and Ari, D. P., 2018. The improvement of indoor air quality (IAQ) by using natural and mechanical method. AIP Conference Proceedings 1984, 020018. https://doi.org/10.1063/1.5046602.

[25] Kim, K. J. M. J., Kil, M. I., Jeong, H. D., Kim, E. H., Yoo, S. J., Jeong, C. H. and Pak, K. C. Son., 2009. Determination of the efficiency of formaldehyde removal according to the percentage volume of pot plants occupying a room. Kor. J. Hort. Sci. Technol. 27: 305-311.

[26] Kim, K. J., M. J., Kil, M. I., Jeong Dong Woo Lee, S. J., Jeong, H. D., Kim, E. H., Yoo, S. J., Jeong and Han, S. W. 2010. Variation in Formaldehyde Removal Efficiency among Indoor Plant Species. HORTSCIENCE 45 (10): 1489-1495.

[27] Statistical Analysis System (SAS Institute)., 2011. SAS software, release $6.08 .6^{\text {th }}$ ed., Inc. Cary, NC, USA.

[28] Gaëlle, G., Max, H. S. and Iain, S. W., 2018. Smart ventilation energy and indoor air quality performance in residential buildings: - A review. Energy and Buildings, ELSEVIER Volume 165, pp 416-430.

[29] Soni, V., Singh, P., Shree, V. and Goel, V., 2018. Effects of VOCs on Human Health. In: Sharma N., Agarwal A., Eastwood P., Gupta T., Singh A. (eds) Air Pollution and Control. Energy, Environment, and Sustainability. Springer, Singapore. 